\title{
Os Direitos Fundamentais da Personalidade Moral (À Integridade Psíquica, à Segurança, à Honra, ao Nome, à Imagem, à Intımidade)*.
}

\author{
Antônio Chaves \\ Professor Catedrático de Direito Civil na \\ Faculdade de Direito da Universidade de \\ São Paulo
}

SUMÁrIo: 1. Introdução. 2. O reconhecimento legislativo da dignidade humana. 3. O respeito à integridade psíquica. 4. Direito à intimidade. 5. Direito ao segredo. 6. O Conselho de Defesa dos Direitos da Pessoa Humana. 7. Os direitos da personalidade no Projeto de Código Civil de 1975.

\section{Introdução.}

Os direitos fundamentais da personalidade, numa divisão empírica, podem ser abordados:

1. com relação ao elemento corporal do indivíduo: direitos à vida, ao próprio corpo e às partes do mesmo (transplantes, operações cirúrgicas), direito ao cadáver, etc.; 2. com relação à parte imaterial ou moral: respeito à integridade psíquica, à segurança, à honra, ao nome, à imagem, à intimidade.

Ambos os aspectos foram por nós estudados no terceiro volume da Parte Geral das minhas Lições de Direito Civil, Ed. Bushatski, 1972, p. 133-229.

E rápida, no entanto, a tal ponto a evolução desta matéria, que novos desdobramentos vão surgindo a cada momento, alguns dos quais tive oportunidade de analisar, no que diz respeito à primeira daquelas modalidades, em palestra proferida

* Palestra proferida, em resumo, nos dias 8 e 9 de novembro de 1977, nas Faculdades de Direito respectivamente da Universidade Mackenzie e das Faculdades Metropolitanas Unidas, de S. Paulo. 
em agosto deste ano, num ciclo comemorativo do sesquicentenário da Faculdade de Direito da Universidade de S. Paulo, publicada pela Revista de Direito Civil, pela Revista de Informação Legislativa, e pela Revista daquele tradicional estabelecimento de ensino.

Com relação à segunda modalidade, colhemos alguns subsídios novos, que procuraremos sintetizar na presente exposição.

\section{O Reconhecimento Legislativo da Dignidade Humana.}

No âmbito não corpóreo, as prerrogativas do homem civilizado poderiam ser compendiadas numa só palavra: dignidade.

Tão fundamental, que compreende todas as demais, tão transcendente, que sobrepaira às Constituições para ir abrigar-se na própria Declaração Universal dos Direitos do Homem, de 1948, cujo preâmbulo consigna:

"Considerando que o reconhecimento da dignidade inerente a todos os membros da família humana e de seus direitos iguais e inalienáveis é o fundamento da liberdade, da justiça e da paz no mundo;

Considerando que o desprezo e o desrespeito pelos direitos do homem resultaram em atos bárbaros que ultrajaram a consciência da humanidade e que o advento de um mundo em que os homens gozem de liberdade de palavra, de crença e da liberdade de viverem a salvo do temor e da necessidade foi proclamado como a mais alta aspiração do homem comum;

Considerando ser essencial que os direitos do homem sejam protegidos pelo império da lei, para que o homem não seja compelido, como último recurso, à rebelião contra a tirania e a opressão;

Considerando que os povos das Nações Unidas reafirmaram, na Carta, sua fé nos direitos fundamentais do homem, na dignidade e no valor da pessoa humana e na igualdade de direitos do homem e da mulher, e que decidiram promover o progresso social e melhores condições de vida em uma liberdade mais ampla;

Considerando que os Estados Membros se comprometeram a promover, em cooperação com as Nações Unidas, o respeito universal aos direitos e liberdades fundamentais do homem e a observância desses direitos e liberdades." 
Em memorável discurso, teve oportunidade o senador Franco MonToro de alinhar uma série de citações, a começar por SUMMER WELLES:

"Nosso mundo livre deve ser fundado sobre as quatro liberdades: liberdade de palavra e de religião, libertação da penúria e do medo" (O Mundo das Quatro Liberdades, tradução de Fernando Tude de Souza, 1944, p. 170).

JACQUES MARITAIN, no seu Humanismo Integral, já havia destacado a importância dessa verdade fundamental:

“... não é por uma liberdade abstrata, pela liberdade impessoal, é por liberdades concretas e positivas, encarnadas em instituições e corpos sociais, que a liberdade interior da pessoa clama para traduzir no plano externo e social". - (Tradução de Afrânio Coutinho, 1942, p. 193).

OliveIRa VIANa diria a mesma coisa, nas suas Instituições Políticas do Brasil, ao estudar o problema da realização da democracia no Brasil:

"O que o nosso povo-massa pede aos governos eleitos ou não eleitos, pouco importa - é que eles não o inquietem no seu viver particular. Equivale dizer: o que interessa ao nosso povo-massa é a liberdade civil e individual. Este amor pela liberdade (e não propriamente pela democracia) já bem o compreendera José Bonifácio quando dizia: "Os brasileiros são entusiastas do belo ideal, amigos de sua liberdade e mal sofrem perder as regalias que uma vez adquiriram."

$\mathrm{E}$, finalizando:

"Garantir a liberdade civil ao povo-massa: eis o problema central da organização democrática do Brasil"' (Op. cit. II, p. 227/8, 1949).

Mas um tratamento legislativo orgânico das liberdades civis não foi ainda dispensado à importante matéria, circunscrevendo-se o direito positivo pátrio a dois diplomas fundamentais : a Lei n. ${ }^{\circ}$ 4.898, de 09-12-1965, que Regula o Direito de Representação e o Processo de Responsabilidade Administrativa Civil 
e Penal, nos casos de abuso de autoridade, e a Lei $n^{\circ} 5.250$, de 09-02-1967, que Regula a liberdade de manifestação do pensamento e de informações.

Cingindo-nos, aqui, à primeira, consignemos que o art. $3 .^{\circ}$ enumera os atentados que constituem abuso de autoridade:

a) à liberdade de locomoção;

b) à inviolabilidade do domicílio;

c) ao sigilo da correspondência;

d) à liberdade de consciência e de crença;

e) ao livre exercício do culto religioso;

f) à liberdade de associação;

g) aos direitos e garantias legais assegurados ao exercício do voto;

h) ao direito de reunião;

i) à incolumidade física do indivíduo.

São prerrogativas garantidas pela constituição federal, art. 153, nos parágrafos correspondentes: a) 12,20 e 26 ; b) 10 ; c) 9 ; d) 5 ; e) 6 ; f) 28 ;g) 8 ; h) 27 ; i) 14 .

Outras ainda não figuram nessa enumeração: liberdade de pensamento, $\S 8 .^{\circ}$; liberdade de exercício de qualquer trabalho, ofício ou profissão, $\S 23$; liberdade de ação, $\S 2 .^{\circ}$, etc.

O Deputado JosÉ Alves teve oportunidade de oferecer Projeto de Lei (n. ${ }^{\circ}$ 741-B, de 1972), de cuja ampla discussão dá notícia o Diário do Congresso Nacional (Seção I), de 16-031977, págs. 829-833, acrescentando mais a alínea j) aos direitos e garantias legais assegurados ao exercício profissional.

Mas em se tratando de liberdade, não é possível deixar de mencionar outrossim a Lei $n^{\circ} 4.215$, de 27-04-1962, Estatuto da Ordem dos Advogados do Brasil, que a proposta do Deputado JosÉ ALVES garantiria amplamente, permitindo ao profissional examinar em qualquer repartição policial, civil ou militar, independentemente de procuração, autos de flagrante e de inquérito, findos ou em andamento, ainda que conclusos à autoridade, podendo copiar peças e tomar apontamentos.

Mais, a proposição abrangeria, na sua proposital amplitude, não apenas a missão do advogado, mas outrossim a dos jornalistas, dos repórteres, dos fotógrafos dos cinegrafistas, de todos os profissionais, enfim, cuja missão é informar, do mesmo modo que o professor, o investigador, o cientista. 
Em seu apoio manifestou-se também o Deputado CANTídio SAMPAIo (mesmo Diário), encarecendo a importância fundamental da Lei n. ${ }^{\circ} 4.898$ no campo da defesa dos direitos humanos. Editada no Governo Castello Branco tem por objetivo estabelecer medidas inibitórias principalmente ao excesso da autoridade policial, que tende a cometer abusos.

"Infelizmente, decorridos quase 12 anos, ainda a Nação não se acostumou às cláusulas desse diploma, para fazê-lo funcionar com rigor e oportunidade, de molde a que suas sanções sejam aplicadas fazendo regredir essa onda de abuso de autoridade que por vezes causa sérias apreensões à opinião pública nacional."

Trata-se de lei rigorosa que pode ser exercida tanto no plano judicial como no administrativo - e a sanção mais imediata e direta é a perda do cargo e função, desde que evidenciada num processo regular a infração acusada pela parte ofendida. Embora não conheça caso em que ela haja alcançado um resultado prático, será mister que nos acostumemos às suas disposições, que lhe demos vida e eficácia, pois, na realidade, é um dos instrumentos mais expeditos a serem utilizados na busca desse fundamental interesse social e humano.

0 projeto aprimora este edito e lhe supre uma lacuna que salta aos olhos, já que, realmente, não há uma garantia de caráter criminal ao livre exercício da profissão. E todo o direito que jaz assim, desprotegido, praticamente, se transforma numa disposição lírica, sem nenhum sentido prático. Refere ter presenciado, principalmente no que tange ao exercício da função do advogado, barreiras e violências absolutamente intoleráveis. Quando Secretário de Segurança Pública, em São Paulo, foi obrigado a baixar portaria exigindo das autoridades policiais que rendessem aos advogados os direitos preceituados na Lei n. ${ }^{0} 4.215$.

\section{O Respeito à Integridade Psíquica.}

Se apenas com relação ao preso e ao presidiário cuida a Constituição Federal, art. 153, § 14, de impor, exclusivamente a todas as autoridades, o respeito à integridade não apenas física, mas também moral, nem o Código Civil, nem os Projetos ORLANDO GOMES, ou o de 1975 cuidam da preservação da personalidade moral do indivíduo, à qual pelo menos uma referência contém o Código Civil italiano, que, no art. 2087 preocupa-se em obrigar o empresário a tomar as providências 
que, na conformidade da particularidade do trabalho, da experiência e da técnica, são necessárias à proteção "da integridade física e da personalidade moral dos prestadores de trabalho".

O próprio Código Penal Pátrio revela zelo somente no que diz respeito ao uso de substância entorpecente, ou que determine dependência física ou psíquica, sem autorização ou de desacordo com determinação legal ou regulamentar (art. 281), vez por outra, como que incidentemente, ou de má vontade, referindo-se à eventualidade de resultar, no caso justamente de seqüestro e cárcere privado, à vítima, em razão de maus tratos ou da natureza da detenção, grave sofrimento físico ou moral.

A Lei 5.726, de 29-10-1971, que "Dispõe sobre medidas preventivas e repressivas ao tráfico e uso de substâncias entorpecentes ou que determinem dependência física ou psíquica e dá outras providências", e seu Regulamento, Decreto $n .{ }^{\circ}$ 69.845, de 27-12-1971, deram margem à publicação de dois valiosos trabalhos: Tóxicos. Prevenção. Repressão, de VICENTE Greco Filho, S. Paulo, Saraiva, 1972, 294 páginas, e Tóxicos. Aplicações da Lei n.o 5.726, de 1971, de J. L. V. DE AZEVEDo FrancESCHINI, S. Paulo, Ed. Revista dos Tribunais, 1973, 132 páginas.

No capítulo relativo às lesões corporais, reprime o Código Penal apenas as ofensas à integridade corporal ou à saúde de outrem, não dando claramente guarida aos atentados à integridade psíquica do indivíduo o art. $129, \S 20^{\circ} \mathrm{n} .{ }^{\circ}$ II que cuida da ofensa de que resulte "enfermidade incurável".

E justamente sob esse aspecto amplo e compreensivo: o do respeito à integridade psíquica do indivíduo, que, a par da física, é o binômio sobre o qual assenta a própria "estrutura" do indivíduo, que PIETRo PerLINGIeri, La Personalità Umana nell'Ordinamento Giuridico", Camerino, Jovene, 1972, versa externamente, estudando principalmente a oportunidade e a legitimidade dos tratamentos psiquiátricos.

Encarece apresentar-se a alteração mental como uma noção que pode ser expressa em termos não somente médicos, mas também culturais, sociológicos, antropológicos; fato orgânico e/ou fato sociológico-cultural:

"As formas de alteração mental encontram o mais das vezes a sua origem na sociedade: o problema consiste em determinar um ponto de confluência entre 
a esfera individual, apenas formalmente autônoma, e a esfera por assim dizer coletiva; um ponto de confluência entre a gênese da denominada doença mental e a sociopsiquiatria, também no que diz respeito às diferenças existentes entre a psiquiatria e a neurologia. A dificuldade de individuação da noção de alteração mental coloca portanto em crise também a outra de tratamento "médico".

Encarece que se o espírito pertence à estrutura da pessoa e constitui parte integrante da sua personalidade, o tratamento psicoterapêutico encontra o seu limite natural no respeito da pessoa e das suas manifestações. Antes de mais nada, preventivamente, removendo os obstáculos de ordem econômica e social que impedindo o pleno desenvolvimento da pessoa humana constituem as verdadeiras causas de muitos desequilíbrios mentais.

Em segundo lugar, na tentativa de eliminar os mais macroscópicos "desvios", é necessário inspirar-se, mais ainda que na legislação ordinária, sob muitos aspectos atrazada ou lacunosa, nos princípios constitucionais, principalmente nas normas constitucionais italianas que, depois de terem afirmado, de modo solene, que a proteção da saúde é um "direito fundamental do indivíduo" (art. 32, 1), especifica que "ninguém pode ser obrigado a um determinado tratamento sanitário a não ser por disposição de lei", acrescentando que "a lei não pode em caso algum violar os limites impostos pelo respeito da pessoa humana" (alínea 2).

Reconhecendo embora que a solução do problema da legitimidade do tratamento não deve e não pode inspirar-se exclusivamente no perfil subjetivo do consentimento do interessado, acrescenta que se o enfermo mental se apresenta perigoso para a vida ou para a incolumidade sua e dos outros, seria impossível, além de supérfluo, pedir-lhe o consentimento para proporcionar-lhe os cuidados necessários, inclusive os psicoterapêuticos.

Atingindo o ponto mais delicado, consigna tratar-se também de um problema de sensibilidade: intervir na psique do sujeito somente porque manifeste sintomas de anormalidade, além de perigoso, é arbitrário, e o limite pode até mesmo assumir a atitude de instrumento de repressão dirigido a levar a efeito uma modificação das idéias do paciente, cometendo violência com relação às suas convicções religiosas, políticas, sociais, filosóficas, em suma, na sua visão do mundo. 
"A história da loucura é freqüentemente a história dos livres pensadores, dos indivíduos não aceitos pela sociedade, destinados a permanecer dela excluídos; de modo que constitui um erro negar à loucura, e de forma absoluta, a função expressiva de uma verdade diferente $\mathrm{e}$ anticonformista, às vezes destinada a tornar-se a verdade de amanhã. O caráter relativo e histórico da normalidade na vida social deve induzir a maior respeito das originalidades do homem e pois a garanti-lo das intervenções tendentes a torná-lo conforme ao modelo da maioria ou ao modelo que se propõe o político."

Insiste em que tudo se traduz no respeito ao espírito, ao livre desenvolvimento e à atuação da personalidade individual como valor humano e cultural inestimável:

"Il problema della tutela dell'integritá psichica è, quindi, piú grave del problema dell'integrità fisica, anche se l'attenzione dei giuristi, e dei medici legali, si sia concentrata esclusivamente su quest'ultimo."

Daí retira a ilação de que, se a psicoterapia, da mesma forma que não constitui um interesse juridicamente merecedor de proteção quando represente expressão de uma moda alagadora em determinados ambientes - devendo ser estigmatizada atingindo sem temores aqueles que com finalidade de lucro se prestem a satisfazer semelhante moda - assim também constitui um tratamento sócio-sanitário que não pode permanecer uma custosa terapia de elite, excluída da assistência obrigatória.

De tal forma que, quando considerado oportuno o tratamento psicoterapêutico, o sujeito, sem embargo da sua liberdade de decisão, tem direito aos necessários cuidados: a carência legislativa na matéria viola, a seu entender, a própria determinação constitucional italiana (arts. 32 e 38).

Conclui encarecendo que o jurista deve empenhar-se mais do que o médico, ou da maior parte dos psicoterapeutas, numa análise sociológica, histórica e política do problema:

"A proteção e a integridade do espírito e da visão do mundo do sujeito é o mais elevado valor ao qual inspirar-se para a solução dos problemas jurídicos a que dão lugar as técnicas psicoterapêuticas, o método pelo qual julgar o compromisso político do 
psicoterapeuta, o seu "papel" na sociedade: desde o estritamente médico e aparentemente neutro, ao compromissado na crítica ou na apologia do sistema."

Papel relevantíssimo para a melhoria da saúde mental da população em geral, particularmente das classes menos favorecidas, desempenhará certamente o Plano Integrado de Saúde Mental, cujo preparo no Ministério da Saúde levou mais de um ano e que deveria ser implantado em todo o País no período de 1977-1978.

Destina-se a possibilitar o atendimento preventivo e precoce dos doentes mentais, que hoje ocupam $23 \%$ dos leitos hospitalares, por meio de atendimento ambulatorial a cargo das Secretarias de Saúde estaduais. De início, o p̄lano será implantado nas regiões metropolitanas com maior fluxo de doentes, expandindo-se pelo interior do País na medida do possível, em integração com o Programa de Interiorização de Ações Simplificadas de Saúde - PIASS.

Um dos itens considerados mais importantes na nova política de saúde mental é a promoção de mudanças de atitude, conceitos e participação da comunidade na recuperação do doente mental, hoje totalmente segregado da sociedade e vivendo internado em clínicas e hospitais especializados para psicopatas. Para tanto, o Ministério da Saúde já liberou em 1977 verbas no valor de $\operatorname{Cr} \$ 38$ milhões.

Particular importância assume, em nossos dias, o direito à liberdade psiquica, principalmente sob o aspecto da aversão à violência para obter a confissão do acusado, por meio de drogas e narcóticos.

Se é admissível o uso da narcoanálise para usos psiquiátricos, é geral a repulsa como processo de investigação criminal, realçando José CASTAN TOBENAS, com apoio em CUELlo CaLón os graves inconvenientes práticos que oferece, e, mais do que isso, o sério atentado contra a personalidade, por anular o domínio da consciência no sujeito submetido à investigação, ocasionando a inibição de suas faculdades volitivas.

"Algumas dessas práticas" - complementa ORLANDo Gomes, Direitos de personalidade, in Revista Forense, v. 216, 1966 - "podem ser toleradas em atenção ao fim superior a que se destinam, desde que a preocupação terapêutica não se sobreponha à dignidade pessoal do paciente. Condenável, no entanto a todas as luzes, é o processo de desintegração da 
consciência que se vem usando para obter confissões. A monstruosidade das câmaras chamadas mágicas onde se processam as alucinantes lavagens do cérebro não tem paralelo na História. Nem há de se permitirem outros atentados à dignidade humana, como os que se ensaiam com a narcoanálise e com a absorção de drogas que permitem teledirigir a conduta do homem".

O médico Alexander Podrabinek, residente na União Soviética, enviou em julho de 1977 ao Secretário da Amnesty International, com sede em Londres, um samizdat (publicação clandestina) sob o título de Medicina Punitiva, revelando, como resultado de três anos de pesquisa, em toda a sua crueza, a violência psiquiátrica empregada na URSS como meio de repressão dos dissidentes.

Um resumo publicado pelo O Estado de $S$. Paulo de 04-09-1977 revela ser coisa corriqueira recorrerem as autoridades soviéticas à psiquiatria como meio de repressão.

Calcula que havia na ocasião pelo menos mil pessoas internadas por motivos políticos - e não médicos - nos hospitais psiquiátricos especiais do país (isto é, em instituições para psicopatas criminosos de "especial periculosidade", encontrando-se um número maior ainda em hospitais psiquiátricos comuns (isto é, civis).

A sorte das vítimas não é decidida pelas leis do Estado, e sim pelos órgãos de segurança do mesmo, limitando-se os tribunais a cumprir as instruções.

Editorial do referido órgão da imprensa da mesma data lembra que a bem documentada monografia serviu como base das duas resoluções do VI Congresso Mundial de Psiquiatria, na ocasião reunida em Honolulu.

Uma moção de censura apresentada pelo Real Colégio Britânico de Psiquiatria - que condena os "abusos sistemáticos da psiquiatria com fins políticos na União Soviética" e recomenda a criação de comissão internacional encarregada de zelar para que práticas desse tipo sejam evitadas em todos os países do mundo - foi aprovada por 99 votos contra 88. O Congresso aprovou, também (por 121 votos contra 66), projeto de resolução apresentado pela Associação Psiquiátrica Norte-Americana, que condena o "mau uso da profissão, dos conhecimentos e de instalações psiquiátricas para repressão a dissidentes políticos, em qualquer parte onde ocorra". 
Afinal, a consciência da humanidade acordou e reagiu contra essa prática sistemática na União Soviética, denunciada há anos por esse destemido defensor dos direitos humanos, ALEXANDER SOLZHENITSYN, como forma de "assassínio do espírito" e "variação da câmara de gás".

Ressalta o editorial que os órgãos de segurança do Estado têm o poder de determinar a prisão de um contestador qualquer e confiná-lo em um psihuski, mesmo sem submetê-lo a exame psiquiátrico, quando, em seu douto entender, "as condições mentais do paciente tornam tal exame impossível".

Para que o caráter científico de tal decisão não possa ser questionado, o doutor Morozov, que dirige a delegação soviética no Congresso de Honolulu, esclareceu: "O problema da imputabilidade e da não-imputabilidade será resolvido de maneira plenamente científica só com base na filosofia marxistaleninista". Com base na "razão de Estado" soviética. Quem com ela não se conforma sofre a doença mais grave: a "falta de adaptação social".

"Os métodos de curar ou de eliminar tais doenças mentais" - conclui o editorial "são descritos no documento. Espancamentos sádicos, surras brutais, "imobilização compulsória", drogas como sulfazina, aminazina, triftazina, haloperidol, injeções de enxofre, são usadas para tornar doentes mentais os homens sãos, quando não para matá-los. Em nome da ciência, da psiquiatria, do humanismo — ou seja em nome da "razão de Estado" marxista-leninista.

\section{Direito à Intimidade.}

Avulta dia a dia o relevo deste direito, pouco versado pelos tratadistas de há apenas algumas décadas.

Qualificando-o como "riservatezza", define-o ADRIANo DE CUPIS como aquele modo de ser da pessoa que consiste na exclusão do alheio conhecimento daquilo que tem referência à mesma pessoa. Consiste num modo de ser negativo do indivíduo com relação aos outros sujeitos e mais precisamente ao conhecimento destes, satisfazendo aquela necessidade de ordem espiritual que reside na exigência de isolamento moral, de nãocomunicação externa do que diz respeito à pessoa individual, constituindo, assim, uma qualidade moral da própria pessoa.

Vários atos internacionais de grande importância consagram esse direito a começar pela Declaração Universal dos 
Direitos do Homem, da 0NU, de 1948, art. 12, dispondo que nenhum indivíduo poderá ser submetido a interferências arbitrárias na sua vida privada, na sua família, na sua casa, na sua correspondência, etc.

A Declaração de Bogotá, de 1948, preceituou, em seu art. $5 .^{\circ}$, que "Toda pessoa tem direito à proteção e à sua vida privada e familiar", e, mais categoricamente, o art. $80^{\circ}$ da Convenção Européia para a Salvaguarda dos Direitos do Homem e das Liberdades Fundamentais, de 1950, consignou que "toda pessoa tem direito ao respeito de sua vida privada e familiar".

o novo Código Penal, revogado sem entrar em vigor, Decreto-lei n. ${ }^{\circ}$ 1.004, de 21-10-1969, introduzira a figura do crime de Violação de intimidade:

"Art. 16. Violar, mediante processo técnico, o direito à intimidade da vida privada ou o direito ao resguardo das palavras ou discursos que não forem pronunciados publicamente:

Pena - detenção, até um ano, ou pagamento não excedente a cinqüenta dias-multa."

Respigando cuidadosamente os textos legais pátrios. descobre Milton FeRnandes, Proteção Civil da Intimidade, S. Paulo, Saraiva, 1977, que, sem que o legislador o pretendesse, os artigos 554, considerando uso nocivo da propriedade o prejuízo do sossego do vizinho; 573, na parte final, vedando a abertura, em prédio próximo, de janela, eirado, terraço ou varanda, a menos de metro e meio de outro já existente, e 577 do Código Civil, dispondo que, em prédio rústico, não se poderão, sem licença do vizinho, fazer novas construções, ou acréscimos às existentes, a menos de metro e meio do limite comum, asseguram a intimidade doméstica.

Aplaude a manifestação do magistrado BASILEU RIBEIRo FilHo no relatório apresentado ao V Congresso da União Internacional dos Magistrados, O Juiz e o respeito do direito à vida privada, acentuando a curiosidade de oue tais regras, das mais antigas, digam respeito à proteção da vida privada na sua essência, sem que intervenha interesse de qualquer outra natureza: sem dúvida, no centro do problema, o direito de não ser importunado pela curiosidade alheia, sem necessidade de demonstrar qualquer outro prejuízo.

Esmiúça, em seguida, os dispositivos dos Códigos de Processo Civil e Penal relativos às exceções opostas ao princípio da publicidade dos atos processuais. 
Dèmonstra Milton Fernandes que o direito à intimidade estende-se às pessoas jurídicas: as indústrias são ciosas de seus segredos, o comércio mantém em sigilo as próprias iniciativas, mesmo as pessoas jurídicas de direito público, interno e externo, guardam para si muitas informações.

Da análise da doutrina deduz não haver argumento válido que fundamente a negativa: têm as pessoas jurídicas uma intimidade que deve ser legalmente protegida.

Lembra que desta convicção está imbuído nosso direito positivo: Decreto n..$^{\circ}$ 57.690, de 01-02-1966, que aprovou o regulamento para a execução da Lei $n .^{\circ} 4.680$, de 18 de junho do ano anterior, reguladora da profissão de publicitário, cujo art. $17, n .^{\circ} \mathrm{I}, b$, veda divulgar informações confidenciais relativas a negócios ou planos de clientes-anunciantes.

A Lei das Sociedades por Ações n. ${ }^{\circ}$ 6.404, de 15-12-1976, art. 260 impõe ao ofertante, a instituição financeira intermediária e à Comissão de Valores Mobiliários sigilo sobre a oferta pública projetada, respondendo o infrator pelos danos que causar.

O Código de Menores, Decreto n. ${ }^{\circ}$ 17.943-A de 12-10-1927 procura, nos arts. 171 e $172 \S 1 .^{\circ}$, exigindo diligências em segredo de justiça, evitar que eventual escândalo torne irrecuperável a criança, sem cogitar da vida privada da mesma.

Mas é a Lei $n^{\circ}$ 4.655, de 02-06-1965, que dispõe sobre a legitimidade adotiva, que com mais rigor, "tendo em vista as conveniências do menor, o seu futuro e bem-estar", determina ordene o Juiz as diligências e sindicâncias que julgar necessárias, "correndo, contudo, o processo em segredo de justiça" (art. 5. $.^{\circ}, \S 1 .^{\circ}$ ); determina que o mandado ao Registro Civil seja arquivado, dele não podendo o oficial fornecer certidões (art. 6..$^{\circ}$, caput) ; que das certidões do registro nenhuma observação possa constar sobre a origem do ato $\left(\S 1 .^{\circ}\right)$, cominando as penas do art. 325 do Código Penal pela violação do segredo, salvo decisão judicial, ao funcionário responsável (art. 8.․).

A legislação de diferentes países procura submeter 0 desenvolvimento da técnica a uma regulamentação adequada, que objetive impedir a invasão da intimidade pelas teleobjetivas, pelas gravações clandestinas, pela captação de indiscrições de empregados domésticos e ulterior divulgação por qualquer meio.

0 direito à própria imagem está evidentemente relacionado com o direito à reserva sobre a intimidade. Mas diversas outras 
manifestações podem ocorrer, compreendidas numa fórmula genérica como a do Código Civil português: privada.

"Art. 80 Direito à reserva sobre a intimidade da vida

1. Todos devem guardar reserva quanto à intimidade da vida privada de outrem.

2. A extensão da reserva é definida conforme a natureza do caso e a condição das pessoas."

Complementa-o o art. 81 cominando a nulidade de toda limitação voluntária ao exercício dos direitos de personalidade, se for contrária aos princípios da ordem pública e estatuindo que a limitação voluntária, quando legal, é sempre revogável, ainda que com obrigação de indenizar os prejuízos causados às legítimas expectativas da outra parte.

A perícia, principalmente em matéria de anulação de casamento sob invocação de defeitos congênitos, é sempre delicada, envolvendo o respeito à própria intimidade.

Mais delicada ainda nos casos de operações em órgãos sexuais para "mudança de sexo".

A matéria teve que ser enfrentada num pedido de habeascorpus preventivo em favor de uma testemunha indicada como vítima de emasculação decorrente de intervenção corretiva, em inquérito policial instaurado contra o cirurgião, para que a ela se assegurasse a faculdade de impedir o exame pericial solicitado.

Mas o Juiz Benini CABral, da 11. a Vara Criminal de S. Paulo, segundo noticia a imprensa de 28-03-1976, denegou a ordem, ponderando que tais exames médicos são sempre feitos por profissionais, médicos, em recinto apropriado, cercado de normal recato.

Vexação também não constituía o apregoado exame para formalizar o corpo de delito, corolário normal do inquérito, peça de rotina em procedimentos tais. Coação inexistia até porque, como vítima, obrigatórias se tornam suas declarações e, em decorrência, o necessário exame de corpo de delito.

Por outro lado, a autoridade policial pode tomar as medidas tendentes à concretização de tais peças, porque lhe cumpre preparar o procedimento investigatório. $\mathrm{O}$ indigitado exame médico figura como providência essencial "in casu". 
Sendo o crime de ação pública, a autoridade agia no exercício de suas funções e no interesse público. Havia, pois, o dever de obediência, conjugando-se competência e legitimidade.

"Por derradeiro, mencione-se que o paciente já passou por outro exame e o resultado dele ficou exposto nos autos, não sendo a matéria tratada e os pontos examinados crivados de segredo de justiça, e pertinem, agora, a um inquérito em andamento, para cuja solução se exige novo exame, aproveitando-se o anterior, no que for aproveitável, a critério dos peritos médicos, agora indicados.

E, para tal exame, o paciente irá acompanhado, se quiser, de médico de sua escolha, que o assistirá, sem intervir na perícia a ser elaborada. Independentemente de qualquer escolta, ou coerção, porque, no dia aprazado, espontaneamente poderá se fazer presente. Ou, se não comparecer, sem justificado motivo, ser conduzido ao exame, pelos legais meios de que a lei penal dispõe.

Ninguém é obrigado a não fazer o que a lei permite, ou a fazer o que ela não manda."

Sirva de consolo a verificação de que nem o fato de estarem encerradas em seus túmulos livra as próprias rainhas de situações de certa forma semelhantes.

Em dezembro de 1976, por 140 libras (então, cerca de 3 mil cruzeiros) a Christie's de Londres, leiloou, peças íntimas usadas há mais de cem anos pela veneranda Rainha Vitória.

Do lance constaram um par de calcinhas até o joelho e meias de seda pretas.

Cavalheirescos, os leiloeiros limitaram-se a explicar que as roupas estavam muito bem conservadas, discretamente decoradas e que, pelas dimensões, Sua Majestade, naquela época andava muito gorda.

\section{Direito ao Segredo.}

Como regra geral, reconhece a lei o direito que tem cada qual de resguardar-se da divulgação de fatos que só a ele digam respeito.

Temos aí - anota ADRIANo DE CUPIs - um direito que se coloca dentro do âmbito do direito à reserva, mas que se caracteriza pela proteção mais rigorosa, não somente contra atos de propalação, mas contra quaisquer outros que venham a 
constituir uma intromissão na esfera de conhecimento pessoal, independentemente do maior ou menor alcance subjetivo dessa intromissão.

Demonstra que, intensificando-se a proteção jurídica, o próprio bem jurídico protegido assume lineamento mais nítido: segredo é, sim, reserva, mas algo mais: não somente negativo da pessoa, que justamente está entrincheirada no seu um estado, ou modo de ser negativo da pessoa com referência ao conhecimento alheio, mas um modo de ser completamente segredo, goza deste mais profundo sulco que a separa moralmente dos outros e quer defendê-lo.

A Constituição, em dois incisos do seu art. 153, prevê o segredo domiciliar ( $\S 10$ ), e o de correspondência e de comunicações telegráficas e telefônicas $\left(\S 9 .^{\circ}\right)$; o Código Penal pune, os crimes de divulgação de segredo e o de violação do segredo profissional:

"Art. 153. Divulgar alguém, sem justa causa, conteúdo de documento particular ou de correspondência confidencial, de que é destinatário ou detentor, e cuja divulgação possa produzir dano a outrem:

Pena - detenção de um a seis meses, ou multa de $\mathrm{Cr} \$ 300,00$ (trezentos cruzeiros) a $\mathrm{Cr} \$ 2.000,00$ (dois mil cruzeiros).

Art. 154. Revelar alguém, sem justa causa, segredo, de que tem ciência em razão de função, ministério, ofício ou profissão, e cuja revelação possa produzir dano a outrem:

Pena - detenção, de três meses a um ano ou multa de Cr $\$ 1.000,00$ (um mil cruzeiros) a Cr $\$$ $10.000,00$ (dez mil cruzeiros)".

O Decreto-lei n. ${ }^{\circ} 3.200$, de 19-04-1941, que dispõe sobre a organização e proteção da família, determina no art. $2 .^{\circ}$ que os colaterais do terceiro grau, que pretendem casar-se, requeiram ao juiz que nomeie dois médicos para examiná-los e atestar-lhes a sanidade, acrescentando:

"§ 6. ${ }^{\circ}$. O atestado, constante de um só ou mais instrumentos será entregue aos interessados, não podendo qualquer deles divulgar o que se refira ao outro, sob as penas do art. 153 do Código Penal."

Dois importantes dispositivos contém a respeito a aludida Lei $n .{ }^{\circ} 5.250$. 
O primeiro é o art. $7 .^{\circ}$, caput, que não permite o anonimato no exercício da liberdade de manifestação do pensamento e de informação, mas assegura, no entanto, o sigilo quanto às fontes ou origem de informações recebidas ou recolhidas por jornalistas, rádio-repórteres ou comentaristas.

Consignando tratar-se de uma inovação, consigna DARCY ARruda Miranda, Comentários à Lei de Imprensa, S. Paulo, Ed. Rev. dos Tribunais, 1969, v. I, p. 120 que de igual modo que se assegura aos profissionais liberais o direito ao sigilo, no que se refere às confidências de seus clientes, o mesmo direito devem ter os profissionais indicados, que muitas vezes são obrigados a socorrer-se de fontes que não podem revelar sem infringência do Código Deontológico, tanto mais quanto o art. 154 do Código Penal pune o fato de "revelar alguém, sem justa causa, segredo, de que tenha ciência em razão de funçâo, ministério, ofício, ou profissão, e cuja revelação possa produzir dano a outrem".

O segundo é o art. 71, que não admite que nenhum jornalista, radialista, ou pessoas de cujas referências, alusôes ou frases se infere calúnia, difamação ou injúria, possam ser compelidos ou coagidos a indicar o nome de seu informante ou a fonte de suas informações, não podendo seu silêncio, a respeito, sofrer qualquer sanção, direta ou indireta, nem qualquer espécie de penalidade.

"Não poucas vezes," - aduz o mesmo comentarista - "quem tem uma informação de grande interesse público deixa de divulgá-la, pelo justificado receio de perder o emprego ou a função...

Escudado, porém, pelo sigilo, poderá prestar relevantes serviços à coletividade, esclarecendo, informando, divulgando o que vai pelos escaninhos das áreas governamentais. E o jornalista ou radialista, que colhe a informação preciosa, pode publicá-la ou transmiti-la, sem receio de ser coagido a denunciar a sua fonte de informação, ou o nome de seu informante."

Sem embargo, os arts. 15, a e 27, vi capitulam como crime a publicação ou divulgação de segredo de Estado e de atos e decisões do Poder Executivo e a divulgação, a discussão e a crítica de atos do Poder Executivo e seus agentes em matéria de natureza reservada ou sigilosa. 
Do $\S 10^{\circ}$ do art. 49 , que exclui a responsabilidade civil a prova da verdade, desde que admissível na forma dos arts. 20 e 21, excepcionada no prazo da contestação, nos casos de calúnia e difamação, salvo se o fato imputado, embora verdadeiro, diz respeito à vida privada do ofendido e a divulgação não foi motivada em razão de interesse público, infere MrLToN FERNANDES a primeira referência, em texto legal brasileiro, à intimidade como um todo.

Considera feliz a solução ao fixar o interesse público como limite da privacidade, bem como ao impor as perdas e danos, ainda na hipótese de autenticidade do evento, que não importa, tendo implicado invasão da reserva.

"A intimidade está protegida, dessa forma, contra os meios de comunicação. O amparo, no entanto, está longe de ser o ideal ou mesmo o necessário. Só é concedido se o fato implicar também calúnia ou difamação, o que exclui a tutela da vida privada em si mesma."

Do exame, na legislação pátria, dos casos de tutela da esfera de segredo e privada, não deduz, de forma alguma, a existência de um direito geral à reserva: ao contrário, evidencia a precariedade das nossas leis a respeito.

William L. Prosser, Privacy, in California Law Review, 1960, distingue quatro espécies distintas de invasão na lei da intimidade :

1. Intrusão na intimidade ou na solidão do indivíduo, ou em seus assuntos particulares.

2. Divulgação ao público de fatos privados embaraçosos.

3. Publicidade que coloca a pessoa em falsa perspectiva perante o público.

4. Apropriação, em proveito do réu, do nome e da aparência do autor.

A essa concepção se opôs EdWARd J. BLoustein, Privacy as an aspect of human dignity: an answer to Dean Prosser, in New York University Law Review, 1964.

Na síntese de Milton FERNANDES, a aceitar-se aquela teoria, em vez de um direito relativamente novo, básico e independente que protege um interesse único, fundamental e em parte negligenciado, ter-se-ia mera aplicação de modernas cir- 
cunstâncias de direitos tradicionais que tutelam valores sociais bem identificados e estabelecidos.

Para Bloustein, ao contrário, os casos de atos ilícitos que abrangem a privacidade constituem um todo e envolvem dano único, single tort, que é um insulto à dignidade humana, distinguindo-se dos outros apenas pelos meios através dos quais é perpetrado.

Entende correta o professor das Alterosas a censura de Bloustein ao apontar no ensaio de Prosser, em vez de quatro diferentes interesses da pessoa, apenas quatro modos diversos de invasão da intimidade, interesse conceitualmente único, correndo ainda o risco de ser incompleto:

"Ao distinguir duas espécies de divulgação contrárias à intimidade, a de fatos embaraçosos e a de falsa perspectiva, por exemplo, omitiu a de acontecimentos que, não obstante verdadeiros e independentemente da perplexidade que possam causar, constituem penetração ilícita na esfera privada.

Quanto a Bloustein, sua visão da intimidade como um aspecto da dignidade humana mostra-se incompleta; embora possa sê-lo, não o é necessariamente."

Sintetiza a proteção da vida privada na investigação indiscreta e na divulgação:

"Qualquer que seja a forma assumida pelo atentado, é compreendida por esta classificação. A primeira encerra seja a mera busca de informações, seja a fixação destas através da fotografia, da gravação, ou da escrita. A segunda abrange a comunicação, por qualquer processo, dos dados obtidos."

Acentua ADRIANo DE CUPIS que "o problema da admissibilidade dessas provas, que por atraso técnico, pouca prática e outras dificuldades não têm dado, por ora, resultados processuais sensíveis, se traduz no problema geral da admissibilidade e da importância das provas ilicitamente obtidas e não pode sofrer um tratamento diverso dos outros casos análogos (documentos roubados ou de outra forma subtraídos, correspondência ilicitamente aberta), também aqui se trata manifestamente da violação de direitos da personalidade. Ãs vezes ocorrerá precisamente uma causa de justificação válida 
também para o Direito substantivo; mas de qualquer forma permanece aberto e solucionável com seus princípios autônomos o problema da utilização processual".

Como conciliar a publicidade dos atos processuais, com o segredo de justiça dos processos em que o exigir o interesse público ou que dizem respeito a casamento, filiação, desquite, separação de corpos, alimentos e guarda de menores, exigido pelo art. 155 do Código de Processo Civil, casos em que a própria audiência realizar-se-á a portas fechadas (art. 444)?

A questão foi versada em profundidade por acórdão da Oitava Câmara Cível do Tribunal de Justiça do Distrito Federal de 21-11-1952, Diário da Justiça da União de 21-10-1954, pág. 3.690 , num caso de pedido de anulação de casamento em que "fatos escabrosíssimos foram articulados pelo apelante contra a apelada, de natureza íntima, que dizem respeito à moralidade e bons costumes da família, afetando a honra e o melindre dos postulantes, e, principalmente da ré, acusada de prática sexual aberrante e desprimorosa, decidindo que:

"E do interesse do Estado, e no da própria Justiça, a publicidade dos atos judiciais; mas, os trabalhos da justiça, inclusive a própria audiência ou sessão de julgamento, podem correr em sigilo, desde que assim o exija o decoro ou interesse social principalmente quando esse é o desejo, expresso, de ambas as partes e o litígio diz respeito à honra da família."

Reconheceu o relator, Des. Fernando Maximiliano que os negócios da justiça, mais do que quaisquer outros, devem ser discutidos com fránqueza e sinceridade, para quem quiser ouvir, sem aquelas reservas que fazem duvidar da sua limpidez e da isenção daqueles que estão investidos, legalmente da sua tutela.

Mas, se a publicidade dos atos judiciais é a regra, e de inconfutável acerto, também a exceção terá que ser aceita e está expressamente prevista na lei - "quando o contrário for exigido pelo decoro ou interesse social" (Código de Processo Civil de 1939 - $\left.\operatorname{art} .5^{\circ}\right)$.

Não se trata de originalidade ou inovação perigosa, pois, o legislador brasileiro não fez senão seguir a trilha dos Códigos mais modernos, como o italiano, que, indo a extremo de considerar causa de nulidade a falta de publicidade de audiência, entretanto, confere ao juiz que a dirige o poder de "disporre 
che si svolga a porte chiuse, se ricorrono ragioni di sicurezza dello Stato, di ordine publico o di bucni costume" (art. 128).

0 direito processual alemão também entende que os negócios judiciais praticar-se-ão em audiência pública a menos que a moral ou o decoro, ou a natureza da causa de divórcio, exijam que se celebre de portas cerradas (J. GoDSCHIDT - Derecho processal civil, trad., p. 95).

Os comentadores da nossa lei processual, ao acentuarem os poderes soberanos do juiz na apreciação da conveniência de fazer o julgamento sem a publicidade usual, isto é, em segredo de justiça, esclarecem que essa medida deve ser tomada quando a publicidade do ato redundar em escândalo ou acarretar inconvenientes graves, quando não houver também vantagem em que os fatos, verdadeiramente confidenciais de negócios domésticos, sejam expostos aos olhos do público, o que ocorre quase sempre nos processos de divórcio litigioso, por um daqueles motivos escandalosos, que, se provados em público prejudicariam muito mais do que o segredo do ato realizado assim por exceção (J. M. DE CARvalHo Santos - Código de Processo Civil, interpretado v. I, p. 128; Pedro Batista Martins - Comentários - v. I, p. 87; H. DA Silva LIMA - Código de Processo Comentado - v. I, p. 48).

Este último, magistrado paulista dos mais brilhantes, pondera com muita felicidade o seguinte: "Essa publicidade (dos atos judiciais) não vai, porém, até o extremo de violar o respeito que se deve à moral, à dignidade humana, à paz dos indivíduos e à discreção inerente a certos assuntos.

Em determinados processos como o desquite, a anulação de casamento, pode haver fatos íntimos, circunstâncias escabrosas, cuja revelação seja necessária à instrução da causa, como dispunha o Código de 1939, art. 119, § 2. .

O conhecimento de tais fatos interessa apenas às partes e ao Juiz.

Dar-lhe publicidade é ferir o melindre das pessoas envolvidas no processo, depravar o gosto público pelo escândalo e dificultar a prova pelo constrangi- 
mento que as testemunhas teriam em depor publicamente.

O dever do juiz é então realizar o ato, a portas fechadas, vedando-o à observação pública (p. 48).

E outra orientação não teve a Câmara, atendendo ao pedido de ambas as partes, para que o julgamento se processasse em segredo de justiça.

\section{O Conselho de Defesa dos Direitos da Pessoa Humana.}

A importância que se vem reconhecendo aos direitos da personalidade exige um aceleramento nos mecanismos da sua defesa.

Uma manifestação dessa tendência pode ser localizada no Projeto de Código Civil de 1975:

"Art. 12. Pode-se exigir que cesse a ameaça, ou a lesão, a direitos da personalidade, e reclamar perdas e danos, sem prejuízo de outras sanções previstas em lei. Parágrafo único. Em se tratando de morto, terá legitimação para requerê-la o cônjuge sobrevivente, ou qualquer parente da linha reta, ou colateral até o quarto grau.

Graças à proposição do Deputado BILAC PINTo, em 1956, foi, pela Lei n. ${ }^{\circ} 4.319$, de 13-03-1964 criado, no Ministério da Justiça e Negócios Interiores, o Conselho em epígrafe.

Seus arts. $2 .^{\circ}$ e $3 .^{\circ}$, em virtude da Lei $n .^{\circ} 5.763$, de 15-121971, passaram a ter a seguinte redação:

"Art. 2. ${ }^{\circ}$ - O Conselho de Defesa dos Direitos da Pessoa Humana (CDDPH), será integrado dos seguintes membros: Ministro da Justiça, representante do Ministério das Relações Exteriores, representante do Conselho Federal de Cultura, representante do Ministério Público Federal, Presidente do Conselho Federal da Ordem dos Advogados do Brasil, Professor Catedrático de Direito Constitucional e Professor Catedrático de Direito Penal de uma das Faculdades Federais, Presidente da Associação Brasileira de Imprensa, Presidente da Associação Brasileira de Educação, Líderes da Maioria e da Minoria na Câmara dos Deputados e no Senado Federal. 
$\S 10^{\circ}$ - Os Professores Catedráticos de Direito Constitucional e de Direito Penal serão eleitos pelo CDDPH pelo prazo de 2 (dois) anos, permitida a recondução.

$\S 20^{\circ}$ - A Presidência do Conselho caberá ao Ministro da Justiça, e o Vice-Presidente será eleito pela maioria dos Membros do Conselho."

"Art. $3 .^{\circ}-\mathrm{O} \mathrm{CDDPH}$ reunir-se-á, ordinariamente, 6 (seis) vezes ao ano, e, extraordinariamente, sempre que convocado pelo seu Presidente, por iniciativa própria ou por solicitação de $2 / 3$ (dois terços) de seus membros com a indicação da matéria relevante a ser incluída na pauta de convocação.

$\S 10^{\circ}$ - Salvo decisão contrária tomada pela maioria absoluta de seus membros, as sessões do CDDPH serão secretas, divulgando-se pelo órgão oficial da União e dos Estados a súmula de julgamento de cada processo.

$\S 2 .^{\circ}$ - Vetado."

As atribuições do Conselho são definidas no art. $4 .^{\circ}$ :

$1 .^{\circ}$ - promover inquéritos, investigações e estudos acerca da eficácia das normas asseguradoras dos direitos da pessoa humana, inscritos na Constituição Federal, na Declaração Americana dos Direitos e Deveres Fundamentais do Homem (1948) e na Declaração Universal dos Direitos Humanos (1948) ;

$2 .^{\circ}$ - promover a divulgação do conteúdo e da significação de cada um dos direitos da pessoa humana mediante conferências e debates em universidades, escolas, clubes, associações de classe e sindicatos e por meio da imprensa, do rádio, da televisão, do teatro, de livros e folhetos;

$30^{\circ}$ - promover nas áreas que apresentem maiores índices de violação dos direitos humanos:

a) a realização de inquéritos para investigar as suas causas e sugerir medidas tendentes a assegurar a plenitude do gozo daqueles direitos;

b) campanha de esclarecimento e divulgação;

$4 .^{\circ}$ - promover inquéritos e investigações nas áreas onde tenham ocorrido fraudes eleitorais de maiores proporções, 
para o fim de sugerir as medidas capazes de escoimar de vícios os pleitos futuros;

$5 .^{\circ}$ - promover a realização de cursos diretos ou por correspondência que concorram para o aperfeiçoamento dos serviços policiais, no que concerne ao respeito dos direitos da pessoa humana;

$6 .^{\circ}$ - promover entendimentos com os governos dos Estados e Territórios cujas autoridades administrativas ou policiais se revelem, no todo em em parte, incapazes de assegurar a proteção dos direitos da pessoa humana para o fim de cooperar com os mesmos na reforma dos respectivos serviços e na melhor preparação profissional e cívica dos elementos que os compõem;

$7 .^{\circ}$ - promover entendimentos com os governos estaduais e municipais e com a direção de entidades autárquicas e de serviços autônomos, que estejam, por motivos políticos, coagindo ou perseguindo seus servidores, por qualquer meio, inclusive transferências, remoções e demissões, a fim de que tais abusos de poder não se consumem, ou sejam, afinal, anulados;

8. ${ }^{\circ}$ - recomendar ao Governo Federal e aos dos Estados e Territórios a eliminação, do quadro dos seus serviços civis e militares, de todos os seus agentes que se revelem reincidentes na prática de atos violadores dos direitos da pessoa humana;

$9 .^{\circ}$ - recomendar o aperfeiçoamento dos serviços de polícia técnica dos Estados e Territórios de modo a possibilitar a comprovação da autoria dos delitos por meio de provas indiciárias ;

10 - recomendar ao Governo Federal a prestação de ajuda financeira aos Estados que não disponham de recursos para a reorganização de seus serviços policiais, civis e militares, no que concerne à preparação profissional e cívica dos seus integrantes, tendo em vista a conciliação entre o exercício daquelas funções e o respeito aos direitos da pessoa humana;

11 - estudar e propor ao Poder Executivo a organização de uma divisão ministerial, integrada também por órgãos regionais, para a eficiente proteção dos direitọ da pessoa humana;

12 - estudar o aperfeiçoamento da legislação administrativa, penal, civil, processual e trabalhista, de modo a per- 
mitir a eficaz repressão das violações dos direitos da pessoa humana por parte de particulares ou de servidores públicos;

13. receber representações que contenham denúncias de violações dos direitos da pessoa humana, apurar sua procedência e tomar providências capazes de fazer cessar os abusos dos particulares ou das autoridades por eles responsáveis.

Nos termos do art. $5 .^{\circ}$, o CDDPH cooperará com a Organização das Nações Unidas no que concerne à iniciativa e à execução de medidas que visem a assegurar o efeito dos direitos do homem e das liberdades fundamentais.

Art. $6 .^{\circ}$ - No exercício das atribuições que lhes são conferidas por esta lei, poderão o CDDPH e as Comissões de Inquérito por ele instituídas determinar as diligências que reputarem necessárias e tomar o depoimento de quaisquer autoridades federais, estaduais ou municipais, inquirir testemunhas, requisitar às repartições públicas informações $\mathrm{e}$ documentos e transportar-se aos lugares onde se fizer mister sua presença.

Adita 0 art. $7 .^{\circ}$ que as testemunhas serão intimadas de acordo com as normas estabelecidas no Código do Processo Penal.

Parágrafo único - Em caso de não comparecimento de testemunha sem motivo justificado, a sua intimação será solicitada ao Juiz Criminal da localidade em que resida ou se encontre, na forma do art. 218 do Código de Processo Penal.

Constitui crime, na conformidade do art. $8 .^{\circ}$ :

I - Impedir ou tentar impedir, mediante violência, ameaças ou assuadas, o regular funcionamento do CDDPH ou de Comissão de Inquérito por ele instituída ou o livre exercício das atribuições de qualquer dos seus membros.

Pena - a do art. 329 do Código Penal.

II - Fazer afirmação falsa, negar ou calar a verdade como testemunha, perito, tradutor ou intérprete perante o CDDPH ou Comissão de Inquérito por ele instituída.

Pena - a do art. 342 do Código Penal.

Prevê o art. $9 .^{\circ}$ que no Orçamento da União será incluída; anualmente a verba de dez milhões de cruzeiros, para atender às despesas de qualquer natureza do referido Conselho.

Dois Projetos de Lei, ambos de 1975, foram apresentados; tentando dinamizar o Conselho. 
No intuito de corrigi-lo das alterações sofridas em virtude da Lei $\mathrm{n}^{\circ}$ 5.763, que restringiram suas liberdade, eficácia e publicidade da atuação, porque

“a) aumentou o número de membros do Conselho, assegurando maioria permanente a representantes do Governo, cujos atos, muitas vezes, teriam de ser examinados e julgados pelo mesmo órgão;

b) reduziu o número de reuniões ordinárias e exigiu, para as reuniões extraordinárias, a convocação do Ministro da Justiça ou de dois terços da totalidade dos membros do Conselho;

c) impôs a regra, das reunióes secretas, quando a norma deve ser a publicidade."

o senador Franco Montoro ofereceu o de n. ${ }^{0}$ 12, publicado no Diário do Congresso Nacional, Seção II, de 03-03-1975, págs. 220-223, propondo seja estabelecida publicidade das sessões do Conselho, salvo decisão contrária, em cada caso, tomada pela maioria de seus membros.

Determina que haverá uma reunião mensal ordinária, em dia fixado, e extraordinariamente, quando convocada pelo Ministro da Justiça ou por um terço dos membros do Conselho.

Inclui na composição do mesmo, representantes da Conferência Nacional dos Bispos do Brasil e do Conselho de Reitores das Universidades Brasileiras, visando ampliar a representatividade do Conselho e contribuir, assim, para que ele possa cumprir sua real finalidade, e até mesmo servir como instrumento de distensão política.

O segundo Projeto, de autoria do deputado HUMBERTo LUCENA, é fruto de sua participação, durante quase dois anos, como líder da minoria, das reuniões do Conselho.

Sugere seja ele integrado também pelo Presidente da Conferência Nacional dos Bispos, e, ainda, por representante das Igrejas Evangélicas do Brasil, um Ministro aposentado do Superior Tribunal Militar e um Oficial General indicado pela Chefia do Estado-Maior das Forças Armadas.

Aumenta o número de reuniões ordinárias para duas por mês, e torna públicas, salvo decisão contrária em cada caso, as deliberações do Conselho, e ainda divulgadas no órgão oficial da União e dos Estados onde tenham domicílio as partes envolvidas no processo. 
Poderão, no entanto, ter caráter sigiloso as diligências, investigações e inquéritos relacionados com violações dos direitos humanos.

Em sua justificação, com o Projeto publicado no Diário do Congresso Nacional, Seção I, de 11-06-1975, p. 3.904-3.905, acentua que o que importa, no andamento dos processos relacionados com a violação dos direitos do homem, em qualquer área, é a apuração das denúncias formuladas e a exemplar punição dos implicados em cada caso concreto, cumprindo, assim, o Brasil, os compromissos que assumiu na onU, como nação democrática, ao assinar a Declaração Universal dos Diireitos do Homem.

\section{Os Direitos da Personalidade no Projeto de Código Civil de 1975.}

É consagrado à matéria o Capítulo II do Título I do Livro I da Parte Geral (arts. 11-20).

"Art. 11 - Com exceção dos casos previstos em lei, os direitos de personalidade são intransmissíveis e irrenunciáveis, não podendo o seu exercício sofrer limitação voluntária."

Aplaude MILTON FERnANDEs a intransmissibilidade e a irrenunciabilidade, criticando, porém, a proibição, em termos absolutos, da sua limitação voluntária, pois o consentimento do interessado elimina a tipicidade da lesão do direito mesmo em matéria de intimidade.

Considera incomparavelmente superior a fórmula do art. 164 do Anteprojeto francês, que o Código Civil português repetiu literalmente no primeiro tópico:

“Art. 81 - Limitação voluntária dos direitos de personalidade).

1. Toda a limitação voluntária ao exercício dos direitos de personalidade é nula se for contrária aos princípios da ordem pública.

2. A limitação voluntária, quando legal, é sempre revogável, ainda que com obrigação de indenizar os prejuízos causados às legítimas expectativas da outra parte."

Entende estar a limitação em absoluto acordo com o interesse e a ordem públicos como balizas do direito à vida privada, 
mas aponta como outra omissão do artigo a ausência do elenco dos direitos da personalidade, razão porque propõe a seguinte redação:

"Art. 11 - Toda pessoa tem direito à integridade física, moral e psicológica.

Parágrafo único - Salvo os casos previstos em lei, os direitos da personalidade são intransmissíveis e irrenunciáveis, só podendo sofrer limitação voluntária que não contrarie a ordem pública ou os bons costumes."

$\mathrm{O}$ art. 12 do referido Projeto, já vimos, admite se possa exigir que cesse a ameaça, ou a lesão, a direito da personalidade.

Criticando embora a linguagem pouco ortodoxa do parágrafo, admite o professor da Faculdade de Direito da Universidade Federal de Minas Gerais ter-se colocado, neste ponto, o Projeto em consonância com as tendências contemporâneas, pois, embora se extingam com a morte os direitos da personalidade, sua proteção continua, no interesse da família.

Os artigos 13, 14 e 15 do Projeto já foram abordados ao versarmos a matéria relativa aos atos de disposição do próprio corpo e a tratamento médico ou intervenção cirúrgica com risco de vida.

Ampliando a abrangência deste último dispositivo, oferece emenda aditiva, a exemplo do que dispõe o art. 153 do anteprojeto francês:

"Ninguém pode ser constrangido a submeter-se, com risco de vida ou de invasão de sua vida privada, a tratamento médico e psicológico ou a intervenção cirúrgica."

Quatro dispositivos são dedicados pelo Projeto de Código Civil ao nome:

"Art. 16 - Toda pessoa tem direito ao nome, nele compreendidos o prenome e o nome patronímico."

"Art. 17 - O nome da pessoa não pode ser empregado por outrem em publicações ou representações que a exponham ao desprezo público, ainda quando não haja intenção difamatória." 
Reclama MILTon FERNANDES a deficiente menção ao desprezo público, devendo a norma abranger também a falsa perspectiva, que não redunda necessariamente em desprezo, implicando embora em constrangimento para o portador do nome.

Para evitar os inconvenientes decorrentes da menção casuística a publicações ou representações, e do fato da referência apenas à difamação parecer excluir outras formas de atentado à honra, propõe a seguinte redação:

"O nome da pessoa não pode ser divulgado por qualquer processo que a situe em falsa perspectiva ou exponha ao desprezo público, ainda quando não haja intenção danosa."

Nos termos do Projeto:

"Art. 18 - Sem autorização, não se pode usar o nome alheio em propaganda comercial".

Para evitar o caráter restritivo sugere o professor mineiro o seguinte teor:

"Sem autorização, não se pode usar o nome alheio em propaganda ou com intuito de lucro direto ou indireto."

De nossa parte, complementaríamos com uma referência ao retrato alheio e à produção literária e artística de outrem.

Nos termos do Projeto:

"Art. 19 - o pseudônimo adotado para atividades lícitas goza da proteção que se dá ao nome."

Qualifica o monografista de redundante o amparo oferecido para atividades lícitas, uma vez que a proibição do ato ilícito é uma regra geral que não se circunscreve ao pseudônimo.

Considera inconveniente, por muito ampla, a referência genérica ao pseudônimo, inconveniente contornado pela exigência da notoriedade, formulada pelo art. 74 do Código lusitano, propondo, então:

"O pseudônimo, quando conhecido, goza da proteção conferida ao nome."

Finalmente, propõe o Projeto de 1975:

"Art. 20 - Salvo se autorizadas, ou se necessárias à administração da justiça ou à manutenção 
da ordem pública, a divulgação de escritos, a transmissão da palavra, ou a publicação, a exposição ou a utilização da imagem de uma pessoa poderão ser proibidas, a seu requerimento e sem prejuízo da indenização que couber, se lhe atingirem a honra, a boa fama ou a respeitabilidade, ou se se destinarem a fins comerciais.

Parágrafo único - Em se tratando de morto ou de ausente, são partes legítimas para requerer essa proteção o cônjuge, os ascendentes e os descendentes."

Critica Milton FeRnandes a proposição que exclui da proteção a vida privada, e que não lembrou as cartas confidenciais, a seu ver não compreendidas pela expressão escritos: aquelas destinam-se ao conhecimento de, pelo menos, mais uma pessoa, o destinatário, ao passo que estes têm muitas vezes "cunho nitidamente pessoal, dirigindo-se com exclusividade ao uso do autor, para deleite ou fixação de momentos que lhe merecem lembrança." Como exemplo aponta as anotações sigilosas, os diários, as memórias pessoais, as confissões ou documentos, qualquer que seja a sua natureza, comprobatórios de fato de interesse exclusivo do possuidor.

Propõe o tratamento, em artigos autônomos, das cartas missivas confidenciais, de outros escritos e memórias e da imagem, nos seguintes termos:

"Art. 21 - As cartas missivas confidenciais só podem ser divulgadas com o consentimento do seu autor.

Parágrafo único - Razões de relevante interesse público podem determinar o suprimento judicial deste consentimento.

Art. 22 - Aplicam-se às memórias familiares, aos escritos confidenciais e outros do mesmo gênero as disposições do artigo antecedente.

Art. 23 - As cartas não confidenciais só podem ser divulgadas quando o seu conhecimento não causar embaraço ao autor.

Art. 24 - A imagem de uma pessoa não pode ser captada, exposta, reproduzida ou divulgada sem sua autorização. 
Parágrafo único - dispensada a anuência referida neste artigo quando a captação, exposição, reprodução ou divulgação se justificarem pela notoriedade da pessoa interessada, pelo cargo que exerça, por razões de ordem policial ou judicial, científica ou cultural ou por interesse público."

Parece-nos restritiva a expressão "confidenciais" contida no primeiro desses artigos. Sabido como é que se o corpus mechanicum, o papel que recebe a carta, pertence ao destinatário, o corpus misticum, isto é, a composição, a produção literária, seja qual for o seu valor, é reservada ao seu autor, tal como foi redigida a proposição dá a impressão que as cartas missivas não confidenciais podem ser divulgadas sem o consentimento do seu autor, único juiz dessa conveniência.

Acolhendo a sugestão, o Deputado TANCREDo Neves, Presidente da Comissão Especial constituída para dar parecer sobre o Projeto de Código Civil, considerando que na sociedade de consumo, apelos publicitários são comumente feitos sem o necessário resguardo da intimidade alheia, deu à matéria, englobando tudo em artigo único, a seguinte redação:

"Art. 25 - Toda pessoa tem direito à proteção da própria intimidade.

Parágrafo único - Salvo se autorizadas ou necessárias à administração da justiça ou à manutenção da ordem pública, a divulgação de escritos, documentos, cartas confidenciais, do nome, do pseudônimo, a transmissão da palavra, a exposição ou utilização da imagem de uma pessoa, qualquer que seja o fim a que se destinam estes atos, poderão ser proibidas a seu requerimento e sem prejuízo da indenização que couber, por dano material ou moral."

Depois de incluir proposição relativa à tutela da coleta de informações em bancos de dados, conclui Milton FERNANDES sua importantíssima contribuição com o seguinte dispositivo sobre a vida privada:

"Art. 26 - Toda pessoa tem direito à proteção da intimidade própria, da família e do domicílio. 
Parágrafo único - Qualquer ato de invasão desta intimidade pode, de acordo com a condição do interessado, ser proibida mediante requerimento ao juiz, sem prejuízo da indenização, que couber, por dano material e moral." 